\title{
ANALYSIS OF THE PROCESS STRATEGY IN CATFISH FARMING MITRA MAKMUR TULUNGAGUNG
}

\author{
Rafika Meilia Sari \\ Department of Management FEB UMM \\ E-mail: pikameylisa@gmail.com
}

\begin{abstract}
The research aims is to determine time process duration of catfish cultivation. Processing chart used to analyse time determination in cultivation process. Processing chart shows a series of activities, operating time cycle, value-added time, and non value-added activities. The result shows that to produce 1 pool of catfish need 80 days with 1.5 eficiency level. Catfish size was standardized in harvest time and the farmer earn some profits.
\end{abstract}

Keyword: time, production process, process chart

\section{PENDAHULUAN}

Konsumsi ikan lele pada beberapa tahun ini mengalami peningkatan karena permintaan konsumen yang semakin meningkat (Aquarista, 2012). Perkembangan bisnis perikanan dari tahun ke tahun dibuktikan dengan pertumbuhan dan perkembangan produksi ikan lele yang rata-rata mencapai $2,76 \%$ per tahun 2011 di Jawa Timur. Dengan peningkatan tersebut tentunya kebutuhan ikan lele masih mengalami kekurangan. Kekurangan persediaan ikan lele tersebut bisa disebabkan oleh beberapa permasalahan, salah satunya terjadi pada proses pembesaran.

Keuntungan usaha budidaya ikan lele sangat bergantung pada kemampuan pembudidaya mengatur strategi proses pembesaran ikan lele. Namun pada kenyataannya, banyak peternak ikan hanya mengandalkan kondisi ikannya saja dalam menjalankan aktivitas produksi tanpa merencanakan proses dari satu tahapan pengerjaan ke tahapan pengerjaan lainnya, sehingga waktu yang diperlukan guna menghasilkan produk tidak sesuai dengan keinginan (Jaja, 2013). Pada kondisi seperti ini salah satu alat untuk penyelesaian masalah adalah dengan penerapan strategi pada proses produksi yang memiliki dampak jangka panjang terhadap kinerja proses termasuk efisiensi, efektivitas, dan produktivitas sistem (Heizer dan Render, 2008).

Seperti penelitian yang dilakukan Aprilliyanata Citra Pertiwi (2012) menyatakan bahwa perancangan sistem kerja atau adanya strategi proses sangat penting dilakukan pada manajemen operasi karena berkaitan erat dengan produkstivitas dan dapat menunjang tercapainya tujuan perusahaan secara efektif. Pada penelitian lain, menurut Zainal Arif (2012), pentingnya perbaikan proses yang dilakukan secara terus menerus maka dengan sendirinya produk yang dihasilkan 
juga akan memenuhi prosedur yang telah ditetapkan.

Budidaya Ikan Lele Mitra Makmur di Tulungagung merupakan salah satu perusahaan yang bergerak di bidang pembesaran ikan lele konsumsi. Untuk memenuhi kebutuhan pasar, distributor memerlukan ikan lele siap konsumsi yaitu ukuran 7 sampai 14 ekor perkilo gramnya sebanyak satu sampai satu setengah ton dari peternak ikan setiap sekali panen.

Dari survei yang telah dilakukan, masalah yang dihadapi oleh peternak ikan Mitra Makmur adalah pada kinerja proses produksinya. Permasalahan tersebut seperti pada proses pemesanan benih yang kedatangannya harus menunggu pengiriman dari supplier sehingga menyebabkan pengerjaan proses selanjutnya tertunda. Pengambilan ikan siap panen oleh distributor masih belum dapat dipastikan waktunya oleh peternak ikan Mitra Makmur. Distributor mengambil hasil panen hanya mengandalkan konfirmasi dari peternak ikan, sehingga waktu pengambilan ikan siap panen belum terjadwal dengan baik, hal tersebut juga menyebabkan ukuran ikan lele tidak sesuai standar saat dipanen. Masalah lain yaitu pada waktu tunggu antara kegiatan satu ke kegiatan selanjutnya yang lama waktunya belum teratur dengan baik.

Beberapa permasalahan yang dihadapi peternak ikan Mitra Makmur tersebut dapat menyebabkan waktu yang diperlukan guna menghasilkan produk tidak sesuai dengan keinginan dan jadwal panen ikan tidak dapat diprediksi. Dari kondisi tersebut, didukung dengan teori-teori serta dilengkapi dengan data dan fakta yang ada, terdapat masalah pokok yaitu, Berapa lama waktu proses produksi pada Budidaya Ikan Lele Mitra Makmur Tulungagung?, serta tujuan penelitian yaitu untuk mengetahui berapa lama waktu proses produksi pada Budidaya Ikan Lele Mitra Makmur Tulungagung.

\section{TINJAUAN PUSTAKA}

Ishak (2010) menyatakan bahwa Proses adalah setiap bagian dari organisasi yang mengambil input dan mentransformasikannya menjadi output, yang diharapkan akan memiliki nilai tambah bagi organisasi dibanding dengan input awalnya. Suatu proses yang tidak sesuai dengan kebutuhan perusahaan akan merugikan perusahaan tersebut setiap menit perusahaan tersebut beroperasi.

Menurut Taylor dalam buku Joko (2004), mendefinisikan Proses Produksi sebagai langkah-langkah yang diperlukan untuk mengubah/mengkonversi input (sumber daya manusia, bahan baku, peralatan, dan sebagainya) menjadi suatu output barang maupun jasa dimana akibat proses transformasi ini nilai output menjadi lebih besar dari nilai input.

Menurut Heizer dan Render (2008), Strategi Proses atau Strategi Transformasi adalah sebuah pendekatan organisasi untuk mengubah sumber daya menjadi barang dan jasa. Tujuan strategi proses adalah menemukan suatu cara memproduksi barang dan jasa yang memenuhi persyaratan dari pelanggan dan spesifikasi produk yang ada dalam batasan biaya dan batasan manajerial lainnya. Strategi proses dilihat dari jenis proses yaitu, fokus pada proses, fokus berulang, focus pada produk, 
fokus kustomisasi massal.

Beberapa alat analisis dan desain proses yang digunakan pada strategi proses antara lain adalah Diagram Alir, Pemetaan Fungsi Waktu, Pemetaan Aliran Nilai, Diagram Proses, dan Perencanaan Pelayanan. Salah satu alat analisis yang dapat digunakan adalah Diagram Proses. Menurut Heizer dan Render (2008), Diagram Proses (process chart) menggunakan simbol, waktu, dan jarak untuk mendapatkan cara yang objektif dan terstruktur untuk menganalisis dan mencatat berbagai aktivitas yang membentuk sebuah proses.

Menurut Joko (2004), Diagram Proses atau biasa disebut Diagram Alur Proses (Flow Chart) adalah diagram yang menjelaskan alur kegiatan produksi mulai dari datangnya bahan baku sampai produk jadi yang dapat diamati secara kasat mata. Diagram ini memerlukan 5 (lima) buah simbol untuk menjelaskan kegiatan yang terjadi pada proses produksi.

Berdasarkan teori-teori di atas dapat disusun kerangka pikir sebagai berikut:

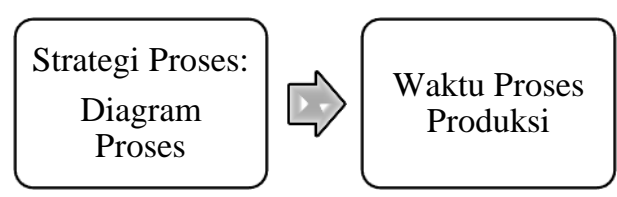

Gambar 1.

Kerangka Pikir Penelitian

\section{METODE PENELITIAN}

Lokasi Penelitian yang dijadikan objek penelitian adalah pada Budidaya Ikan Lele Mitra Makmur yang bertempat di Desa Domasan,
Kecamatan Kalidawir, Kabupaten Tulungagung, RT. 004/RW. 002.

Jenis penelitian yang dipilih adalah Penelitian Terapan (Applied Research) dengan tipe penelitian aksi (action research), yaitu penelitian yang bertujuan untuk mengembangkan keterampilan atau pendekatan baru dan memecahkan masalah tertentu.

Terdapat tujuh variabel pada Diagram Proses yang dapat diukur, yaitu Jarak atau Tujuan, Waktu, Operasi, Transportasi atau Pemindahan, Pemeriksaan, Penundaan Operasi, dan Penyimpanan.

Dalam penelitian ini menggunakan data primer yang bersumber dari pelaksanaan proses, jarak tempuh dan lama waktu yang dibutuhkan dalam menjalankan proses pada Budidaya Ikan Lele Mitra Makmur.

Teknik pengumpulan data yang digunakan adalah Observasi atau Pengamatan. Menurut Widayat (2004), Observasi meliputi kegiatan pencatatan pola perilaku orang, objek dan kejadian-kejadian dalam suatu cara sistematis untuk mendapatkan informasi tentang fenomenafenomena. Alat analisis yang digunakan dalam penelitian ini adalah strategi

proses dengan menggunakan Diagram Proses.

Langkah-langkah analisis strategi proses dengan menggunakan Diagram Proses menurut Heizer dan Render (2008) yang sudah diolah, dimulai dari, mengklasifikasikan kegiatan produksi sesuai simbolsimbol diagram proses. Menentukan waktu yang dibutuhkan pada masingmasing kegiatan. Menentukan jarak pemindahan pada masing-masing 
kegiatan. Memasukkan data pada Diagram Proses.

\section{HASIL PENELITIAN DAN PEMBAHASAN}

Berikut adalah langkahlangkah analisis strategi proses dengan menggunakan Diagram Proses. Klasifikasi kegiatan produksi sesuai simbol-simbol diagram proses.

Lingkaran $(\bigcirc)$ menggambarkan suatu kegiatan operasi. Segi Empat ( $\square$ ) menggambarkan kegiatan inspeksi (pemeriksaan). Anak Panah ( $\vec{b}$ ) menggambarkan pemindahan (transportasi). Huruf D Besar (D) menggambarkan kegiatan menunggu atau disebut juga penundaan operasi. Segitiga Terbalik $(\nabla)$ menggambarkan kegiatan penyimpanan.

Menentukan waktu yang dibutuhkan pada masing-masing kegiatan dengan pengamatan sebanyak tiga kali produksi ikan lele. Budidaya Ikan Lele Mitra Makmur memiliki ukuran kolam yang berbedabeda mulai dari ukuran $2,5 \times 5 \mathrm{~m}, 4 \mathrm{x}$ $10 \mathrm{~m}, 6 \times 12 \mathrm{~m}, 8 \times 20 \mathrm{~m}$ dengan kedalaman rata-rata $2 \mathrm{~m}$. Pengamatan dilakukan pada pada 1 kolam yang sudah ditentukan ukurannya yaitu ukuran $6 \times 12 \times 2 \mathrm{~m}$ yang memiliki ukuran yang sedang, kemudian diambil nilai rata-rata yang nantinya akan diukur pada diagram proses. Pengamatan waktu tersebut dijelaskan pada Tabel 1.

Menentukan jarak pemindahan pada masing-masing kegiatan, yaitu Jarak tempuh pengiriman atau pengambilan benih dari supplier ke tempat budidaya. Jarak pemindahan ikan sisa hasil panen dari kolam produksi ke kolam ikan sisa. Memasukkan data pada Diagram Proses. $\begin{array}{ccc}\text { Dari } & \text { hasil } & \text { analisis } \\ \text { mengounakan } & \text { Diagram } & \text { proses, }\end{array}$ diperoleh 27 aktivitas pada aliran proses, Waktu yang dipakai dalam operasi yang menghasilkan nilai tambah adalah 0,516 hari. Waktu total siklus operasi atau lama waktu proses produksi adalah 79,788 hari atau 80 hari. Sehingga waktu yang terpakai untuk menghasilkan nilai tambah atau tingkat efisiensi waktu setelah dihitung menggunakan diagram proses pada setiap kolam adalah 1,546 persen dan 98,454 persen lainnya digunakan untuk proses produksi kolam lainnya yaitu 34 kolam.

Dari hasil tersebut peternak ikan dapat mengetahui lama proses produksi ikan lele, dapat menentukan jadwal pelaksanaan kegiatan proses produksi, serta dapat mengetahui kapan ikan lele siap dipanen. Sehingga panen ikan dapat dilakukan secara rutin dengan ukuran yang sesuai standar saat dipanen, disisi lain peternak ikan memperoleh keuntungan lebih dengan adanya pemanenan ikan lele tepat waktu.

\section{SIMPULAN}

Berdasarkan hasil penelitian dan pembahasan yang telah dilakukan maka dapat ditarik kesimpulan bahwa dari yang sebelumnya waktu yang dibutuhkan untuk satu kali produksi adalah sekitar tiga hingga empat bulan.

Setelah dilakukan analisis dengan menghitung proses produksi menggunakan Diagram Proses pada 1 kolam ikan lele dari 35 kolam selama tiga kali pengamatan produksi ikan lele, diperoleh waktu total siklus operasi atau lama waktu proses produksinya adalah 80 hari dengan tingkat efisiensi waktu pada kolam yang dianalisis adalah 1,546 persen. 
Tabel 1. Waktu Proses Produksi Pembesaran Ikan Lele dari Tiga Kali Pengamatan pada Budidaya Ikan Lele Mitra Makmur Tulungagung

\begin{tabular}{|c|c|c|c|c|c|c|}
\hline No. & Kegiatan & $\begin{array}{l}\text { Pengamatan. } \\
1 \\
\text { (dlm menit) }\end{array}$ & $\begin{array}{c}\text { Pengamatan. } \\
2 \\
\text { (dlm menit) }\end{array}$ & $\begin{array}{c}\text { Pengamatan. } \\
3 \\
\text { (dlm menit) }\end{array}$ & $\begin{array}{l}\text { Waktu } \\
\text { rata-rata } \\
(\text { dlm } \\
\text { menit })\end{array}$ & $\begin{array}{c}\text { Waktu } \\
\text { rata-rata } \\
(\mathrm{dlm} \\
\text { hari) }\end{array}$ \\
\hline 1. & $\begin{array}{l}\text { Penyiapan } \\
\text { kolam }\end{array}$ & 60 & 60 & 60 & 60 & 0,041 \\
\hline 2. & $\begin{array}{l}\text { Menunggu } 1 \\
\text { Pengiriman/ }\end{array}$ & 2880 & 2880 & 4320 & 3360 & 2,333 \\
\hline 3. & $\begin{array}{l}\text { Pengambilan } \\
\text { benih }\end{array}$ & 280 & 300 & ) & 290 & 0,201 \\
\hline 4. & $\begin{array}{l}\text { Pemeriksaan } \\
\text { mutu benih }\end{array}$ & 12 & 16 & 13 & 14 & 0,010 \\
\hline 5. & $\begin{array}{l}\text { Penyortiran } \\
\text { benih }\end{array}$ & 155 & 215 & 160 & 177 & 0,123 \\
\hline 6. & $\begin{array}{l}\text { Pemasukan } \\
\text { benih }\end{array}$ & 13 & 12 & 12 & 12 & 0,008 \\
\hline 7. & Menunggu 2 & 18720 & 17280 & 18720 & 18240 & 12,667 \\
\hline 8. & $\begin{array}{l}\text { Penambahan } \\
\text { air } 1\end{array}$ & 45 & 45 & 45 & 45 & 0,031 \\
\hline 9. & Menunggu 3 & 18720 & 18720 & 17280 & 18240 & 12,667 \\
\hline 10. & $\begin{array}{l}\text { Penambahan } \\
\text { air } 2\end{array}$ & 40 & 40 & 30 & 37 & 0,026 \\
\hline 11. & Menunggu 4 & 18720 & 17280 & 18720 & 18240 & 12,667 \\
\hline 12. & $\begin{array}{l}\text { Penambahan } \\
\text { air } 3\end{array}$ & 30 & 30 & 40 & 33 & 0,023 \\
\hline 13. & Menunggu 5 & 17280 & 18720 & 17280 & 17760 & 12,333 \\
\hline 14. & Ganti air 1 & 50 & 50 & 50 & 50 & 0,035 \\
\hline 15. & Menunggu 6 & 17280 & 18720 & 18720 & 18240 & 12,667 \\
\hline 16. & Ganti air 2 & 50 & 50 & 50 & 50 & 0,035 \\
\hline 17. & Menunggu 7 & 18720 & 17280 & 17280 & 17760 & 12,333 \\
\hline 18. & Ganti air 3 & 50 & 50 & 50 & 50 & 0,035 \\
\hline 19. & Menunggu 8 & 168 & 240 & 216 & 208 & 0,144 \\
\hline 20. & $\begin{array}{l}\text { Pemeriksaan } \\
\text { ikan }\end{array}$ & 5 & 5 & 5 & 5 & 0,003 \\
\hline 21. & Menunggu 9 & 1740 & 1920 & 1680 & 1780 & 1,236 \\
\hline 22. & $\begin{array}{l}\text { Menguras } \\
\text { air }\end{array}$ & 165 & 135 & 140 & 147 & 0,102 \\
\hline 23. & $\begin{array}{l}\text { Pemanenan } \\
\text { ikan }\end{array}$ & 80 & 70 & 95 & 82 & 0,057 \\
\hline 24. & $\begin{array}{l}\text { Pemindahan } \\
\text { ikan sisa }\end{array}$ & 9 & 11 & 10 & 10 & 0,007 \\
\hline 25. & $\begin{array}{l}\text { Pemasukan } \\
\text { ikan sisa }\end{array}$ & 5 & 4 & 9 & 6 & 0,004 \\
\hline
\end{tabular}


Dari hasil tersebut pemanenan atau produksi ikan lele dapat dilakukan secara rutin dengan ukuran ikan lele yang sesuai standar saat dipanen, disisi lain peternak ikan juga memperoleh keuntungan lebih dengan adanya pemanenan ikan lele tepat pada waktunya.

\section{DAFTAR PUSTAKA}

Aquarista, Fenta, Iskandar dan Ujang Subhan. 2012. Pemberian Probiotik dengan Carrier Zeolit pada Pembesaran Ikan Lele Dumbo (Clarias Gariepinus). Fakultas Perikanan dan Ilmu Kelautan UNPAD. Diakses pada September 2014 dari www.google.com.

Arifin, Zainal. 2007. Analisis Perbaikan Teknik Pemeliharaan Guna Efisiensi Biaya Pada CV Lele Edan Gemilang. Universitas Muhammadiyah Malang. Diakses pada Maret 2014 dari www.digilib.ac.id

Hamidi. 2004. Metode Penelitian Kualitatif. Edisi Pertama. UMM Press: Malang.

Haming, Muridfin dan Mahfud Nurnajamudin. 2011. Manajemen Produksi Modern. Edisi Kedua. Bumi Aksara: Jakarta.

Heizer, Jay dan Barry Render. 2008. Operations Management (Manajemen Operasi edisi-9 buku 1). $\quad 9^{\text {th }} \quad$ Edition. Diterjemahkan oleh Chriswan Sungkono tahun 2009. Salemba Empat: Jakarta.

Ijentravel.blogspot.com/2013/02/trav el-malang.html?m=1\#!/2013 02/travel-malang.html. Diakses pada 15 Januari 2015.
Indrianto, Nur dan Bambang Supomo. 2009. Metodologi Penelitian Bisnis untuk Akuntansi dan Manajemen. Edisi Pertama. BPFE: Yogyakarta.

Ishak, Aulia. 2010. Manajemen Opersi. Edisi pertama. Graha Ilmu: Yogyakarta.

Jaja, Ani Suryani dan Komar Sumantadinata. 2013. Usaha Pembesaran dan Pemasaran Ikan Lele serta Strategi Pengembangannya di UD Sumber Rezeki Parung, Jawa Barat. Manajemen IKM. Diakses pada September 2014 dari www.google.com.

Joko, Sri. 2004. Manajemen Operasi dan Produksi (Suatu Pengantar). UMM Press: Malang.

muliaberbagi.blogspot.in/2014/03/bis nis-rumahan-budidaya-ikanlele-dan.html?m=1. Diakses pada 30 Oktober 2014.

Nugroho, Dafi. 2008. Analisis Alur Proses Jasa Pengiriman Pizza pada PT. Sari Melati Kencana (Pizza Hut Malang). Universitas Muhammadiyah Malang. Diakses pada Mei 2014 dari www.digilib.ac.id

Pertiwi, Aprilliyanata Citra. 2012. Evaluasi Alur Proses Jasa .Pelayanan Pembelian Sepeda Motor pada Dealer Honda Mitra Phinastika Mustika Malang. Universitas Muhammadiyah Malang. Diakses pada Mei 2014 dari www.digilib.ac.id

Widayat. 2004. Metode Penelitian Pemasaran. Edisi Pertama. UMM Press: Malang. 
www.alamtani.com/budidaya-ikanlele.html. Diakses pada 14 lele/. Diakses pada 14 September 2014. www.suryamina.com/tahapan-carabudidaya-pembesaran-ikanSeptember 2014.

Yamit, Zulian. 2003. Manajemen Produksi dan Operasi. Edisi kedua. Ekonisia: Yogyakarta 